\title{
Peningkatan Aktivitas Belajar dan Pemahaman Konsep Fisika melalui Model Discovery Learning pada Konsep Getaran Harmonis di Kelas X MIPA 2 SMAN 3 Kota Bengkulu
}

\author{
Vijay Amar, Nirwana, Indra Sakti \\ Program Studi Pendidikan Fisika Jurusan Pendidikan MIPA \\ Universitas Bengkulu \\ Email: vijayamar35@gmail.com
}

\begin{abstract}
ABSTRAK
Penelitian ini merupakan penelitian tindakan kelas yang dilaksanakan di SMAN 3 Kota Bengkulu pada seluruh siswa kelas X MIPA 2 yang berjumlah 36 siswa. Penelitian ini bertujuan untuk mendeskripsikan peningkatan aktivitas belajar dan pemahaman konsep siswa pada konsep Getaran Harmonis. Penelitian ini dilakukan dalam 4 tahap yaitu perencanaan, pelaksanaan tindakan, observasi, dan refleksi. Hasil penelitian ini menunjukkan bahwa aktivitas belajar siswa pada siklus I dengan ratarata skor 24 dalam kategori cukup, siklus II sebesar 28 dalam kategori aktif, dan siklus III sebesar 30 dalam kategori aktif. Hasil Pemahaman konsep fisika pada siklus I diperoleh daya serap sebesar 74,44\% dan ketuntasan pemahaman konsep fisika sebesar 52,78 (belum tuntas), meningkat pada siklus II diperoleh daya serap siswa sebesar $77,71 \%$ dan ketuntasan pemahaman konsep fisika $77,78 \%$ ( tuntas), dan meningkat lagi dibandingkan siklus I dan II yaitu pada siklus III diperoleh daya serap 83,08\% dan ketuntasan pemahaman konsep fisika 94,44\% (tuntas). Berdasarkan hasil penelitian dapat disimpulkan bahwa penerapan model discovery learning dapat meningkatkan aktivitas dan pemahaman konsep fisika.
\end{abstract}

Kata kunci: Pendekatan Saintifik, Model Pembelajaran Discovery Learning, Aktivitas Belajar Siswa, Pemahaman Konsep Fisika.

\begin{abstract}
This research was a classroom action research conducted at SMAN 3 Kota Bengkulu for all students of class X MIPA 2 totaling 36 students. This research aimed to describe the increase of learning activities and understanding of student concepts on the concept of Harmonic Vibration. This research was conducted in 4 stages: planning, action implementation, observation, and reflection. The results of this research indicated that student learning activity on cycle I with average score 24 in the category enough, cycle II of 28 in the active category, and cycle III of 30 in the active category. Results Understanding the concept of physics in the first cycle obtained absorption of $74.44 \%$ and the completeness of physics concepts understanding of 52.78 (unfinished), increased in cycle II obtained students absorption of $77.71 \%$ and comprehension of physics concepts $77.78 \%$ (complete), and increased again compared to cycles I and II ie in the third cycle obtained $83.08 \%$ absorption and comprehension of physics concept $94.44 \%$ (thorough). Based on the research results can be concluded that the application of discovery learning model can increase the activity and understanding of physics concept.
\end{abstract}

Keywords: Scientific Approach, Discovery Learning Model, Student Learning Activities, Understanding Physical Concepts.

\section{PENDAHULUAN}

Pendidikan erat kaitannya dengan sekolah, dari sekolah siswa dapat mempelajari berbagai ilmu pengetahuan yang dapat digunakan dalam kehidupannya. Penyelenggaraan pendidikan di sekolah lebih dikenal dengan pembelajaran yang melibatkan banyak faktor, baik faktor guru, siswa, bahan atau materi, fasilitas dan lingkungan sekolah. Keberhasilan suatu proses pendidikan sangat bergantung pada situasi kegiatan pembelajaran di kelas dan bagaimana siswa dalam mengikuti pembelajaran. Oleh karena itu standar proses pendidikan mengalami 
perkembangan dan perubahan seperti halnya kurikulum yang digunakan sekarang adalah kurikulum 2013 yang dikembangkan dari kurikulum KTSP.

Kurikulum 2013 memiliki standar kompetensi kelulusan yang mencakup sikap, pengetahuan, dan keterampilan. Untuk memenuhi kompetensi kelulusan tersebut proses pembelajaran yang dilakukan dengan aktivitas mengamati, menanya, mengolah, menyajikan, menyimpulkan, dan mencipta. Karena itu kurikulum 2013 menggunakan pendekatan saintifik dalam pembelajaran. Dijelaskan Dyer dalam Sani \& Hayati (2014) pendekatan saintifik dalam pembelajaran memiliki komponen proses pembelajaran antara lain: mengamati, menanya, mencoba/mengumpulkan informasi, menalar/asosiasi, membentuk jejaring (melakukan komunikasi) [1].

Pendekatan saintifik mengedepankan keterampilan proses dalam pembelajaran. Dalam kurikulum 2013 guru sebagai fasilitator siswa untuk mengembangkan aktivitas siswa dalam proses pembelajaran dengan mengharapkan siswa mendapatkan hasil pembelajaran yang lebih baik. Keberhasilan proses pembelajaran ditunjukkan dengan terjadinya perubahan sikap dan perilaku serta peningkatan suatu pengetahuan dari tidak tahu menjadi tahu.

Berdasarkan hasil observasi yang telah dilakukan pada pelaksanaan Magang 3 di SMA Negeri 3 Kota Bengkulu khususnya kelas X MIPA 2 yang menerapkan kurikulum 2013 ditemukan beberapa fakta bahwa: (1) kurangnya antusisas siswa dalam belajar. Saat proses tanya jawab siswa yang aktif hanya 15 siswa dari 36 siswa, karena masih banyak siswa yang belum berani bertanya terkait materi yang dipelajari dan mengungkapkan pendapat di depan kelas. (2) hasil belajar fisika aspek pengetahuan siswa masih belum mencapai ketuntasan minimal yang diterapkan SMAN 3 Kota Bengkulu karena siswa hanya mampu mengerjakan soal yang rumusnya jelas dan sesuai dengan contoh yang diberikan guru, ketika bentuk soal sedikit diubah namun dengan konsep fisika yang sama siswa cenderung bertanya pada guru dan meminta bantuan teman lain yang dianggap lebih pintar. (3) Siswa belum terlatih untuk menjawab soal secara mandiri dan belum terampil menemukan pengetahuan.

Siswa kelas X MIPA 2 belum terlibat aktif secara maksimal dalam melaksanakan proses pembelajaran karena siswa kurang dilatih beraktivitas dalam melakukan eksperimen. Proses mengamati, menanya, mencoba, menyimpulkan, serta mengkomunikasikan kurang optimal dilakukan siswa sehingga siswa kurang terampil menemukan pengetahuannya. Hal ini berpengaruh pada hasil belajar fisika yang diperoleh siswa. Nilai rata-rata ujian siswa kelas X MIPA 2 semester ganjil tahun ajaran 2017/2018 adalah 68 sedangkan ketuntasan minimal yang ditetapkan di SMAN 3 Kota bengkulu yaitu 75, maka nilai ini belum mencapai target yang diharapkan. Hal ini disebabkan kurangnya pemahaman siswa terhadap soal dan materi fisika yang diajarkan. Siswa tidak hanya mengingat dan memahami tetapi juga siswa diharapkan dapat mengaplikasikan dan menganalisis untuk mengetahui seberapa besar siswa menguasai materi fisika dan memahami penjelasan dari guru. Dalam kurikulum 2013 siswa juga dilatih untuk mengerjakan dan memahami soal mengevaluasi dan mencipta. Oleh sebab itu, perlu diadakannya peningkatan aktivitas belajar dan pemahaman konsep fisika di kelas $\mathrm{X}$ MIPA 2.

Pembelajaran berdasarkan kurikulum 2013 dengan pendekatan saintifik siswa menjadi pusat pembelajaran. Siswa lebih dilatih dan diarahkan menemukan pengetahuannya lewat percobaan khususnya fisika dalam proses pembelajaran. Model pembelajaran yang cocok dalam penelitian ini berdasarkan uraian di atas yaitu model discovery learning. Sani \& Hayati (2014) mengungkapkan pembelajaran discovery merupakan pembelajaran kognitif yang menuntut guru lebih kreatif menciptakan situasi yang dapat membuat peserta didik belajar aktif menemukan pengetahuan sendiri [1].

Oleh sebab itu berdasarkan uraian di atas, maka dipandang perlu melakukan penelitian di SMAN 3 Kota Bengkulu dengan judul penelitian"Peningkatan Aktivitas Belajar dan Pemahaman Konsep Fisika Melalui Discovery Learning pada Konsep Getaran Harmonis di Kelas X MIPA 2 SMAN 3 Kota Bengkulu." Adapun rumusan masalah dalam penelitian ini adalah: (1) Apakah penerapan model discovery learning dapat meningkatkan aktivitas 
belajar siswa pada konsep Getaran Harmonis di Kelas X MIPA 2 SMAN 3 Kota Bengkulu ? (2) Apakah penerapan model discovery learning dapat meningkatkan pemahaman konsep siswa pada konsep Getaran Harmonis di kelas X MIPA 2 SMAN 3 Kota Bengkulu ?

\section{METODELOGI PENELITIAN}

Penelitian ini merupakan penelitian tindakan kelas yang dilaksanakan sebanyak 3 siklus. Subjek dari penelitian ini adalah kelas X MIPA 2 SMAN 3 Kota Bengkulu tahun ajaran 2017/2018, yang berjumlah 36 orang siswa, yang terdiri dari 23 orang siswa perempuan dan 13 orang siswa laki-laki.

Teknik pengumpulan data yang digunakan dalam penelitian ini adalah observasi dan tes Pemahaman konsep fisika. Data yang didapatkan adalah aktivitas siswa dan guru, , pemahaman konsep fisika pada setiap siklus. Aktivitas belajar diamati menggunakan lembar observasi pada setiap siklusnya. Penilaian lembar observasi berpedoman pada kriteria penilaian lembar observasi. Pemahaman Konsep Fisika diajarkan melalui lembar kerja siswa dan lembar diskusi siswa untuk melihat pemahaman siswa pada akhir siklus diberikan soal tes evaluasi. Tes evaluasi terdiri dari enam soal essay yang mengandung 6 indikator ranah kognitif yaitu mengingat, memahami, menaplikasikan, menganalisis, mengevaluasi, dan mencipta.

Instrumen tes pada penelitian ini berupa soal essay. Sebelum instrumen tes digunakan, terlebih dahulu harus uji validitas. Uji validitas digunakan untuk mengetahui kevalidan soal tes yang akan digunakan pada penelitian. Adapun, uji validitas yang digunakan pada penelitian ini adalah uji validitas konten (isi).

Data tes pemahaman konsep fisika dianalisa dengan menggunakan rumus rata-rata nilai, daya serap dan ketuntasan pemahaman konsep fisika secara klasikal. Rata-rata, Daya serap dan ketuntasan pemahaman konsep fisika klasikal dikatakan meningkat apabila ratarata, daya serap dan ketuntasan belajar klasikal silklus III lebih baik dari siklus II dan siklus I. Pemahaman konsep fisika dikatakan meningkat apabila nilai siswa pada siklus III lebih baik dari siklus II dan siklus I. Dan dikatakan tuntas apabila siswa mencapai nilai KKM yaitu 75.

1. Nilai Rata - rata

$\bar{X}=\frac{\sum X}{N}$

Ket $: \bar{X} \quad=$ Nilai rata-rata

$\sum X \quad=$ Jumlah nilai pemahaman konsep fisika

$\mathrm{N} \quad=$ Jumlah siswa [2].

2. Standar Deviasi

$$
\mathrm{S}=\sqrt{\frac{(X-\bar{X})^{2}}{N-1}}
$$

Ket : $S=$ Standar deviasi

$\mathrm{X}=$ Nilai siswa

$\bar{X} \quad=$ Nilai rata-rata

$\mathrm{N} \quad=$ Jumlah siswa[3].

3. Ketuntasan Belajar Klasikal

$$
K B=\frac{N^{\prime}}{N} \times 100 \%
$$

Ket : $\mathrm{KB}=$ ketuntasan pemahaman konsep fisika klasikal

$\mathrm{N}^{\prime}=$ jumlah siswa yang skornya $\geq 75$

$\mathrm{N}$ = jumlah siswa keseluruhan

4. Daya Serap

$$
D S=\frac{N S}{s \times N I} \times 100 \%
$$


Ket : DS = daya serap siswa

NS = Jumlah nilai seluruh siswa

$\mathrm{NI}=$ nilai ideal dan

$\mathrm{S} \quad=$ adalah jumlah siswa [4].

\section{Hasil dan Pembahasan}

\subsection{Aktivitas Belajar Siswa Tiga Siklus}

Aktivitas siswa merupakan segala aktivitas belajar siswa pada proses pembelajaran dengan menggunakan model discovery learning. Ada 10 aspek aktivitas peserta didik yang telah diamati pada setiap siklus. Dimana pada siklus I aktivitas belajar siswa masuk dalam kategori baik dan meningkat untuk siklus II dan III. Peningkatan ini disebabkan karena adanya perbaikan-perbaikan kekurangan yang dilakukan guru dan siswa pada tiap siklusnya sehingga proses pembelajaran menjadi lebih baik lagi. Dengan adanya pengingkatan aktivitas belajar siswa, hal ini sangat berpengaruh terhadap pemahaman konsep fisika. Peningkatan aktivitas belajar siswa ini ditunjukan juga pada gambar 1

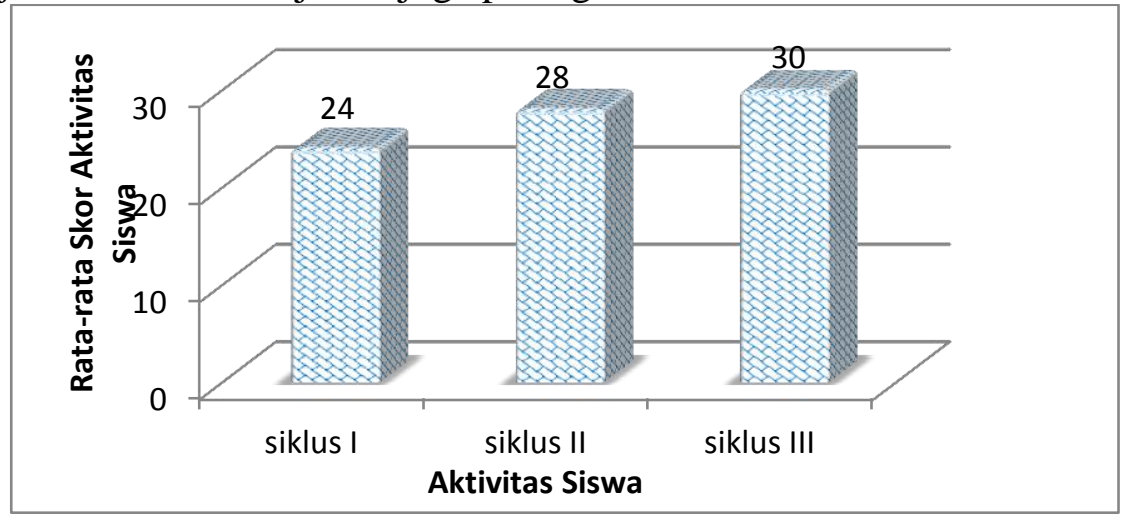

Gambar 1. Grafik Perkembangan Skor Aktivitas Belajar Siswa

Berdasarkan gambar 1, diketahui bahwa aktivitas belajar siswa pada ketiga siklus meningkat dari siklus I ke siklus II dan dari siklus II ke siklus III. siklus I di kategorikan baik dengan rata-rata 24, untuk siklus II dan siklus III dikategorikan baik dengan rata-rata 28 dan 30.

Peningkatan aktivitas belajar siswa tidak lepas dari peranan guru yang memfasilitasi, membimbing, dan mengarahkan serta memotivasi siswa. Kemampuan guru mengemas pembelajaran menjadi menarik menjadi salah satu poin yang bagus untuk menciptakan suasana pembelajaran yang aktif dan kondusif.

\subsection{Pemahaman Konsep pada Tiga Siklus}

Pemahaman konsep fisika tiap siklus terdiri dari 6 butir soal yaitu mengingat, memahami, menerapkan, menganalisis, mengevaluasi, mencipta. Pemahaman konsep fisika merupakan hasil tes yang dilakukan setiap akhir siklus. Tes soal ini berfungsi untuk mengetahui kemampuan dan pemahaman konsep siswa terhadap materi fisika yang diajarkan setiap siklusnya. Tipe soal ini berupa tes 6 soal essay kategori (mengingat, memahami, menerapkan, menganalisis, mengevaluasi, dan mencipta) tiap butir soalnya tentang materi yang diajarkan setiap siklusnya. Adapun perbandingan Pemahaman konsep fisika pada siklus I, siklus II, dan siklus III dapat dilihat pada gambar 2. 


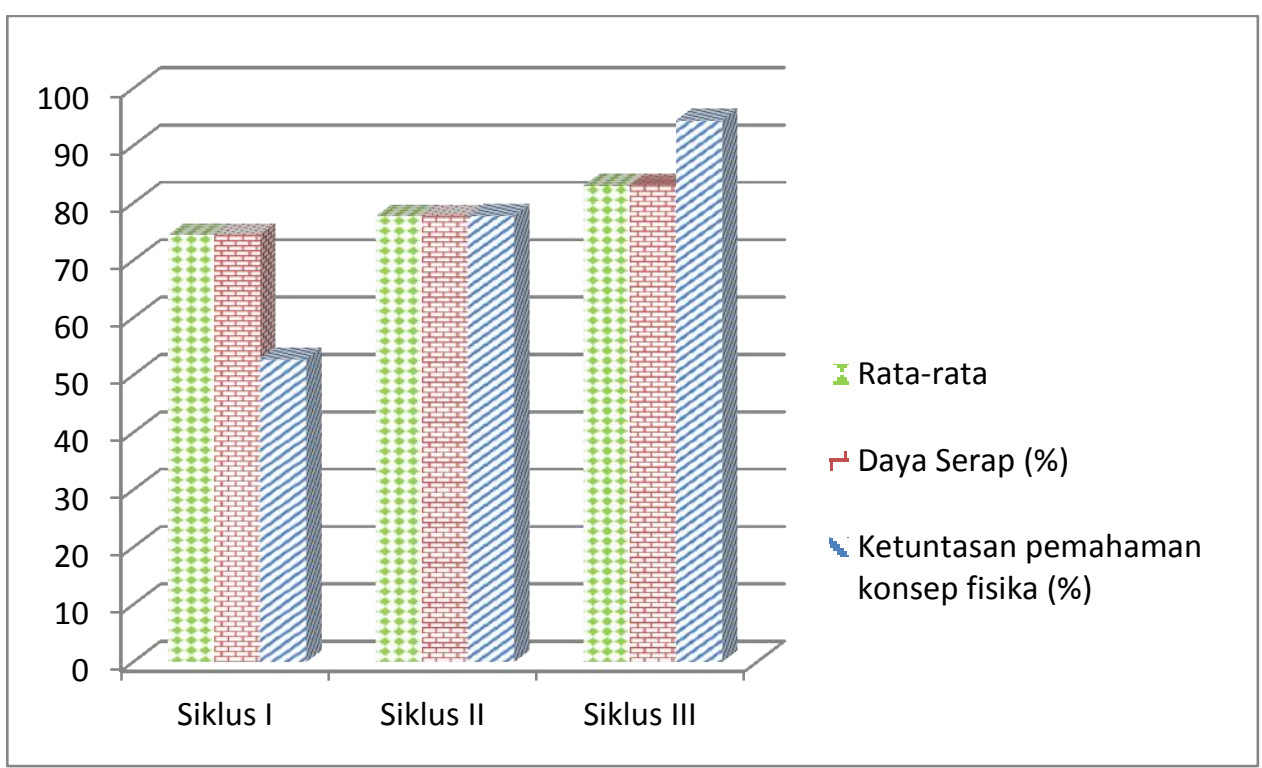

Gambar 2. Grafik Nilai Rata-Rata, Daya Serap dan Ketuntasan Pemahaman Konsep Fisika

Berdasarkan gambar 2 dapat dilihat bahwa pada siklus I diproleh skor rata-rata 74,44 , daya serap $74,44 \%$, dan ketuntasan pemahaman konsep fisika 52,78\%. Secara klasikal pemahaman konsep fisika pada siklus I belum dapat dikatakan tuntas. Hal ini terjadi karena ada beberapa siswa yang belum mencapai nilai ketuntasan yang telah ditetapkan yaitu 75 . Jumlah siswa yang mendapat skor $\geq 75$ sebanyak 19 orang $(52,78 \%)$,. Skor siswa banyak rendah pada butir soal menganalisis, mengevaluasi, dan mencipta. Hal tersebut terjadi karena siswa masih belum terlalu memahami soal menganalisis, mengevaluasi, dan mencipta. Kebanyakan siswa sulit menjawab soal dalam kategori tersebut. Pada siklus 1 soal kategori mengingat dan memahami semua siswa dikatakan tuntas karena telah mendapatkan skor diatas 15 berdasarkan penilaian patokan yang diterapkan SMAN 3 Kota Bengkulu setiap kategori. Pada soal kategori mengaplikasikan ada 24 siswa yang tuntas, kategori menganalisis ada 17 siswa yang tuntas, kategori mengevaluasi ada 18 siswa yang tuntas, dan kategori mencipta ada 19 siswa yang tuntas

Pada siklus II terjadi peningkatan skor rata-rata siswa dari 74,44 pada siklus I menjadi 77,71, daya serap 77,71\%, dan ketuntasan pemahaman konsep fisika $77,78 \%$. Pemahaman konsep fisika pada siklus II ini sudah dikatakan tuntas secara klasikal karena telah lebih dari $75 \%$ siswa mendapat skor $\geq 75$. Ketuntasan pemahaman konsep fisika secara klasikal pada siklus II dikatakan belum tuntas dengan terdapat 8 siswa yang belum tuntas secara individual. Siswa mulai memahami soal kategori tingkat tinggi seperti menganalisis, mengevaluasi, mencipta ketika dijelaskan oleh guru. Pada siklus 1 soal kategori mengingat dan memahami semua siswa dikatakan tuntas karena telah mendapatkan skor diatas 15 berdasarkan penilaian patokan yang diterapkan SMAN 3 Kota Bengkulu setiap kategori. Pada soal kategori mengaplikasikan ada 30 siswa yang tuntas, kategori menganalisis ada 27 siswa yang tuntas, kategori mengevaluasi ada 23 siswa yang tuntas, dan kategori mencipta ada 23 siswa yang tuntas

Pada siklus III, skor rata-rata yang diperoleh siswa adalah 83,08, daya serap 83,08\%, dan ketuntasan pemahaman konsep fisika 94,44\%. Secara klasikal proses pembelajaran pada siklus III dikatakan sudah tuntas karena dari 34 siswa yang mengikuti proses pembelajaran, hanya 2 siswa yang mendapat skor $<75$. Sesuai dengan ketuntasan belajar menurut acuan yang ditetapkan di SMAN 3 kota bengkulu, ketuntasan pemahaman konsep fisika klasikal pada siklus III sudah terpenuhi karena sudah lebih dari 75\% siswa memperoleh skor $\geq 75$. Walaupun seperti itu masih ada siswa yang belum dapat menjawab soal secara maksimal pada soal kategori menganalisis ada 3 siswa yang belum tuntas, kategori mengevaluasi ada 2 siswa yang belum tuntas, dan kategori mencipta ada 3 siswa yang belum tuntas

Peningkatan pemahaman konsep fisika pada tiap siklus ini menjelaskan bagaiamana penguasaan siswa terhadap materi yang diajarkan. Peran guru sebagai motivator, fasilitator 
dan desain pembelajaran sangat membantu siswa dalam belajar. Hal ini sejalan dengan teori belajar kognitif yang menyatakan bahwa pembelajaran dapat dikatakan sebagai upaya guru untuk memberikan stimulus, bimbingan, pengarahan, dan dorongan kepada siswa agar terjadi proses belajar [5]. Berdasarkan uraian diatas, maka dapat kita lihat bahwa penerapan model discovery learning dapat meningkatkan pemahaman konsep fisika.

\section{Kesimpulan dan Saran}

\subsection{Kesimpulan}

Berdasarkan hasil penelitian dan pembahasan diperoleh kesimpulan sebagai berikut : (1) Penerapan model discovery learning dapat meningkatkan aktivitas belajar siswa pada konsep Getaran Harmonis kelas X MIPA 2 SMAN 3 Kota Bengkulu dan (2) Penerapan model discovery learning dapat meningkatkan Pemahaman Konsep siswa pada konsep Getaran Harmonis kelas X MIPA 2 SMAN 3 Kota Bengkulu. Siswa dapat memahami soal dalam kategori mengingat, memahami,mengaplikasikan, menganalisis, mengevaluasi, dan mencipta.

\subsection{Saran}

Berdasarkan penelitian yang telah dilakukan, disarankan perbaikan penelitian dimasa yang akan datang berupa : (1)Guru harus memahami betul langkah-langkah model discovery learning (2)Terdapat beberapa masalah dalam penelitian ini yaitu siswa masih sulit menjawab soal pemahaman konsep fisika karena kurangnya dilatih mengerjakan soal kategori tingkat tinggi seperti menganalisis, mengevaluasi, dan mencipta.

\section{DAFTAR PUSTAKA}

[1] Sani, R. A., \& Hayati, Y. S. (2014). Pembelajran Saintifik Untuk Implementasi Kurikulum 2013. Jakarta: Bumi Aksara.

[2] Arikunto, S. (2009). Dasar-Dasar Evaluasi Pendidikan. Jakarata: Bumi Aksara.

[3] Arikunto, S. (2010). Prosedur Penelitian Suatu Pendekatan Praktik. Jakarta: Rineka Cipta.

[4] Trianto. (2011). Panduan Lengkap Penelitian Tindakan Kelas (Classroom Action Research). Jakarta: Prestasi Pustakaraya.

[5] Abidin, Y. (2014). Desain Pembelajaran dalam Konteks Kurikulum 2013. Bandung: Refika Aditama. 